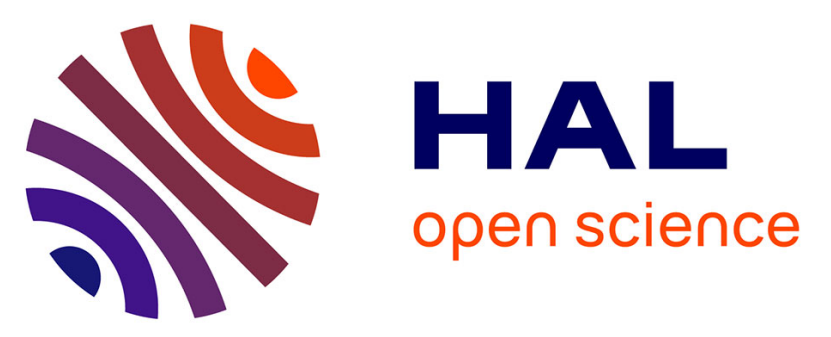

\title{
The metabolic clearance rate of estradiol-17beta in rainbow trout, Salmo gairdneri R., estimated by both single injection and constant infusion methods: increase during oocyte maturation
}

\author{
Jean-François Baroiller, Alexis Fostier, Yonathan Zohar, Odile Marcuzzi
}

\section{To cite this version:}

Jean-François Baroiller, Alexis Fostier, Yonathan Zohar, Odile Marcuzzi. The metabolic clearance rate of estradiol-17beta in rainbow trout, Salmo gairdneri R., estimated by both single injection and constant infusion methods: increase during oocyte maturation. General and Comparative Endocrinology, 1987, 66, pp.85-94. 10.1016/0016-6480(87)90353-4 . hal-02728252

HAL Id: hal-02728252

https://hal.inrae.fr/hal-02728252

Submitted on 2 Jun 2020

HAL is a multi-disciplinary open access archive for the deposit and dissemination of scientific research documents, whether they are published or not. The documents may come from teaching and research institutions in France or abroad, or from public or private research centers.
L'archive ouverte pluridisciplinaire HAL, est destinée au dépôt et à la diffusion de documents scientifiques de niveau recherche, publiés ou non, émanant des établissements d'enseignement et de recherche français ou étrangers, des laboratoires publics ou privés.

\section{()(1)(2)}

Distributed under a Creative Commons Attribution - ShareAlikel 4.0 International 


\title{
The Metabolic Clearance Rate of Estradiol-17 $\beta$ in Rainbow Trout, Salmo gairdneri R., Estimated by Both Single Injection and Constant Infusion Methods: Increase during Oocyte Maturation
}

\author{
J. F. BARoIller, A. Fostier, Y. Zohar, AND O. Marcuzzi \\ Institut National de la Recherche Agronomique, Laboratoire de Physiologie des Poissons. Campus de \\ Beaulieu, 35042 Rennes Cédex, France
}

Accepted May 11, 1986

\begin{abstract}
A dual cannulation of free-swimming rainbow trout is used to estimate the metabolic clearance rate (MCR) of Estradiol-17 $\left(\mathrm{E}_{2}-17 \beta\right)$ by both single injection and constant infusion methods. It is shown that $\mathrm{E}_{2}-17 \beta \mathrm{MCR}$ changes significantly during the progress of oogenesis, mainly at the end of the sexual cycle. The same changes in MCR and very similar values are found with both single injection and constant infusion methods: MCR is stable $(28.8 \mathrm{ml} / \mathrm{hr} / \mathrm{kg}$ ) from the postovulation period (throughout endogenous vitellogenesis) to early exogenous vitellogenesis. It decreases significantly during advanced exogenous vitellogenesis $(18.7 \mathrm{ml} / \mathrm{hr} / \mathrm{kg})$ and increases clearly at the onset of oocyte maturation $(40.9 \mathrm{ml} / \mathrm{hr} /$ kg). A direct relationship between $M C R$ and plasma $E_{2}-17 \beta$ occurs: Plasma $E_{2}-17 \beta$ levels increase (advanced exogenous vitellogenesis) when MCR decreases. Then estradiol decline takes place at the same time that $\mathrm{MCR}$ reaches its highest values (oocyte maturation). An increase in MCR is probably one event required to allow the establishment of an appropriate hormonal environment for oocyte maturation. (c) 1987 Academic Press, Inc.
\end{abstract}

The best known biological activity of estradiol-17 $\beta\left(\mathrm{E}_{2}-17 \beta, 1,3,5(10)\right.$-estratrien$3,17 \beta$-diol) in fish is the hepatic stimulation of vitellogenin synthesis (for review see $\mathrm{Ng}$ and Idler, 1983). However, a role played by estradiol on meiotic maturation and ovulation has also been suggested recently. Estradiol-17 $\beta$ lowers the efficiency of the maturational gonadotropin $(\mathrm{GtH})$ in vitro to induce intrafollicular oocyte maturation in rainbow trout (Jalabert, 1975), and reduces the output by ovarian follicles of $17 \alpha$-hydroxy-20 $\beta$-dihydroprogesterone $(17 \alpha, 20 \beta-$ OH-P,4-pregnen-17 $\alpha, 20 \beta$-diol-3-one), the most potent steroid inducer of this maturation (Fostier et al., 1973; Jalabert, 1976; Jalabert and Fostier, 1984a). Furthermore, a negative estrogen feedback on the pituitary has been shown at the migratory germinal vesicle stage, probably preventing the ovulation surge of $\mathrm{GtH}$ in trout (Bommelaer et al., 1981), although this does not seem to be true in goldfish (Pankhurst and Stacey, 1985). Therefore, the vitellogenic steroid appears to be an antimaturational hormone (Jalabert and Fostier, 1984b) and the decrease in its plasma levels may be an obligatory event prior to spontaneous ovulation. Such decline has been recorded in various salmonid species (Fostier et al., 1978; Jalabert et al., 1978; Fostier and Jalabert, 1982; Scott et al., 1983; Sower and Schreck, 1982; Van der Kraak et al., 1984; Kagawa et al., 1983) and correlated with a decrease of the ovary's ability to secrete estradiol$17 \beta$ (Zohar, 1982; Kagawa et al., 1983), hypothesized to be basically a fall in aromatase activity (Young et al., 1983). However, very little attention has been given to the clearance of the hormone from the blood which plays a significant role in the regulation of its plasma level. Most of the research on clearance of steroids in fish concerns corticosteroids (Idler et al., 1963; Donaldson and Fagerlund, 1968, 1969; Fagerlund and Donaldson, 1969, 1970; Idler and Truscott, 1969; Owen and Idler, 1972; Henderson et al., 1974; Leloup-Hatey, 
1974, 1976; Goodman and Butler, 1976; Truscott et al., 1977; Patino et al., 1985) but very little deals with sexual steroids.

Two methods can be used to estimate the metabolic clearance rate (MCR) of a hormone: (1) the analysis of the disappearance curve of the labeled hormone from the blood after a single rapid injection, and (2) the measurement of steroid entering the blood, once steady state is reached, by means of a constant infusion (Tait, 1963). A continuous infusion of tritiated testosterone was done through the branchial venous system by Fletcher et al. (1969), to estimate testosterone MCR in sexually mature male and female skate, Raja radiata. Blood samples were withdrawn via a second cannula which was put in the caudal artery. Recently, Querat et al. (1982, 1985) chose the single injection method to determine estradiol MCR in immature silver eels; injection and sampling were done through a cannula inserted into the pneumatic artery. To our knowledge, these are the only two studies on sexual steroid MCR in fish. Others works deal with steroid accumulation in various target tissues (Schreck, 1973; Myers and Avila, 1980) or with the problem of the residues' half-life after anabolic treatments (Johnstone et al., 1978; Fagerlund and McBride, 1978; Fagerlund and Dye, 1979; Lone and Matty, 1981; Johnstone et al., 1983) but the methods used here were not appropriate for MCR estimations.

The following study was performed to measure the estradiol metabolic clearance rate in female rainbow trout, at various stages of ovogenesis, mainly during the periovulation period. Both single injection and constant infusion methods were used and compared. For this, the single cannulation technique (Zohar, 1980; Bry and Zohar, 1980) was modified to obtain a dual cannulation of free-swimming trout.

\section{MATERIALS AND METHODS}

Animals. Three-year-old female rainbow trout $(1.3$ to $2 \mathrm{~kg}$ ) were used, most of them belonging to a "winter strain" spawning in November-December. A few animals of a "spring strain," spawning in MarchApril, were also used in the study with the constant infusion method. Fish were kept in a recirculating water system (at $12 \pm 2^{\circ}$ ) and submitted to a natural photoperiod.

At the end of the experiments the fish were killed and weighed. Ovary fragments were fixed in BouinHollande solution and stained by Regaud's hematoxylin and Heidenheim's Azan (Gabe, 1968).

When feasible, the oocyte maturation stage was estimated by observation with a stereomicroscope (Jalabert and Fostier, 1984b).

The following stages were identified:

Advanced endogenous vitellogenesis: Vitellin vesicles (stained blue with Azan) and perinuclear lipoidistic globules appeared.

Beginning of exogenous vitellogenesis: Vitellin granules stained with orange-G were visible in the peripheral cytoplasmic area.

Advanced exogenous vitellogenesis: The vitellin granules spread toward the middle of the cytoplasm, coalesced, and grew in size. The vitellin vesicles transformed into cortical vesicles.

Preovulation stages were defined according to Jalabert and Fostier (1984b):

Subperipheral germinal vesicle (SPGV): The germinal vesicle began to appear at the oocyte periphery and could be observed as a diffuse clear spot at the center of the dark cytoplasm.

Germinal vesicle breakdown (GVBD).

Post-ovulation period: These fish ovulated between the day of cannulation and the end of the constant infusion.

Cannulation. The dorsal aorta catheterization was performed as described earlier by Zohar (1980). Briefly, fish were maintained anesthetized on an operation table, and their gills were perfused with $300 \mathrm{ppm}$ phenoxyethanol solution. An $80-\mathrm{cm}$-long catheter filled with $0.7 \%$ saline solution containing lithium heparinate $(150 \mathrm{IU} / \mathrm{ml})$ was inserted into the dorsal aorta at the midline of the buccal roof, slightly anterior to the first gill bar. For the caudal vessel catheterization, a metal needle with an inner diameter closely fitting the outer diameter of the cannula (Clay-Adams PE-50) was fixed on a 5-ml syringe. The needle was inserted just under the lateral line, a little behind the adipose fin at about a $20^{\circ}$ angle between the skin and needle. Penetration of the vessel was indicated by blood entering into the syringe after pumping slightly. A 120-cm-long catheter filled with heparinate solution (150 IU/ml) was placed into the needle and inserted 8 $\mathrm{cm}$ into the blood vessel; then the guiding needle was gently withdrawn. The cannula was sutured to the skin behind the penetration point and passed along the body through a subcutaneous tunnel made with a 20 -cm-long metal needle; then it was sutured to the skin on its head near the cannula coming from the 
aorta. After surgery, animals were left undisturbed for a period of at least 3 days. Resumption of normal feeding after catheterization (and during constant infusion) was used as a criterion to test the state of recovery (Bry and Zohar, 1980).

When the single injection method was used, both cannula were closed with blocked syringe needles adapted to a cork floater. The steroid injection was done via the caudal vessel and sampling via the dorsal aorta.

When the constant infusion method was used, the cannula coming from the dorsal aorta was connected via a miniature infusion swivel (Harvard-Bioscience, U.K.) to a perfusion pump (Perfusor-Braun, RFA) which released $0.1 \mathrm{ml} / \mathrm{hr}$. The miniature infusion swivel, fixed to the tank cover, allowed fish to swim freely during perfusion. The other cannula was used to sample blood.

Blood samples. Before blood sampling, a 200- $\mu \mathrm{l}$ sample (dorsal aortic cannula), corresponding to the cannula dead space, was discarded. When sampling was completed, the blood filling the cannula was pushed back by $200 \mu$ l of heparinized saline solution. Blood samples were centrifuged at $4^{\circ}(3000 \mathrm{~g} \times 15$ min) and plasma stored at $-20^{\circ}$ until analysis. Blood $(300 \mu \mathrm{l})$ was sampled before injection and at $15-$ and 30 -sec intervals, and then samples were taken after 1 , $2,4,6,8,10,15,20,30$, and $45 \mathrm{~min}$, then again at 1 , $1.5,2,3$, and $4 \mathrm{hr}$ following the single injection. During the constant infusion, lasting 22 to $50 \mathrm{hr}, 8$ to 10 samples of 0.5 to $1 \mathrm{ml}$ of blood were taken.

Hematocrit values. Two or three hematocrit capillaries were filled and sealed just after blood sampling and centrifuged for $3 \mathrm{~min}$ at $15,200 \mathrm{~g}$ (single injection) or $5 \mathrm{~min}$ at $7000 \mathrm{~g}$ (constant infusion). The hematocrit was defined as the volume of packed erythrocytes divided by the total blood volume, expressed as a percentage. The hematocrit value for each sample was then determined by the mean of the values of two or three of its capillaries. Surgery and constant infusion did not affect this hematological data: Hematocrit values were constant before and during the experiment in both methods. Such was the case of all the experimental trout.

Hormones. In both methods $\left[2,4,6,7-{ }^{3} \mathrm{H}\right] \mathrm{E}_{2}-17 \beta$ (Amersham, S.A $93 \mathrm{Ci} / \mathrm{m} M$ ) was used. It was checked for purity by thin-layer chromatography (chloroform: ethanol, 90:10) for the single injection method and, when necessary, purified (chloroform:ethylacetate, $80: 20)$ for the constant infusion method. $\left[4-{ }^{14} \mathrm{C}\right] \mathrm{E}_{2}-17 \beta$ (CEA France, S.A $40-50 \mathrm{mCi} / \mathrm{m} M$ ) was used to determine the recovery of each stage of the biochemical treatment of the samples in the second method. The injected steroid was partially diluted with plasma from the experimental animal to prevent the adsorption to tubing. Thus, the $500 \mu l$ used for the single injection was composed of half $0.7 \%$ saline solution and half plasma; and in the constant infusion experiment trout balanced salt solution, without any glucose or antibi- otic (Jalabert and Fostier, 1984a), was used with $1 \%$ plasma.

In the first case $2-7 \mu \mathrm{Ci} / \mathrm{kg}$ body wt of $\left[{ }^{3} \mathrm{H}\right] \mathrm{E}_{2}-17 \beta$ was injected and in the second case $0.26-0.98 \mu \mathrm{Ci} / \mathrm{hr} /$ $\mathrm{kg}$ body wt was given.

Steroid extraction and purification. In the constant infusion experiment, plasma aliquots were treated with $300-600 \mu$ l of a tissue solubilizer (NCS, Amersham, U.K.) to measure the total plasma radioactivity. To the remaining part of this plasma, $5 \mu \mathrm{g}$ of $E_{2}-17 \beta$ was added (Steraloids) as carrier. All samples were extracted twice with $2 \mathrm{ml}$ cyclohexane-ethylacetate $(50: 50)$; then an aliquot of the total extractable radioactivity was counted, and the remaining extract was chromatographed on Sephadex LH-20 columns. Two different-sized columns were used: $0.5 \times 12 \mathrm{~cm}$ in the single injection treatment with benzene-methanol $(85: 15)$ as eluant (Fostier et al., 1978) and $0.5 \times 8 \mathrm{~cm}$ in the constant infusion method with dichloromethane-methanol (95:5). The estrone and estradiol fractions were collected and their radioactivity measured. For the constant infusion samples, the estradiol fraction was then purified by high-pressure liquid chromatography (HPLC, Waters, pumps M 45 and $6000 \mathrm{~A})$ using a reverse-phase system: Bondapack C-18 column (Waters, diameter $4 \mathrm{~mm}$, length $30 \mathrm{~cm}$ ) eluted with methanol:water (57:43). Estrogens were detected by their absorption at $280 \mathrm{~nm}$ (Detector Waters 440).

The constancy of the ${ }^{3} \mathrm{H} /{ }^{14} \mathrm{C}$ ratio after three successive crystallizations in hexane:ethanol was used as an identification criterion (Axelrod et al., 1965) after addition of $10 \mathrm{mg}$ of the cold $\mathrm{E}_{2}-17 \beta$.

Radioactivity measurements. Organic phases were dried and dissolved in methanol, and a 50- $\mu 1$ aliquot was added with $5 \mathrm{ml}$ OCS scintillator. Plasma digested by the tissue solubilizer was completed with $5 \mathrm{ml}$ liquid scintillation cocktail (Picofluor, Packard). Radioactivity was counted on an Intertechnique SL 4000 counter (France) and expressed in disintegrations per minute (dpm). The tritium content of the sample was corrected for losses during purification, using the ${ }^{14} \mathrm{C}$ recovery.

Data analysis. Single injection: If $R$ is the total radioactivity cleared (the total radioactivity injected) and $x(t)$ the plasma radioactive concentration according to time, the metabolic clearance rate is defined (Tait, 1963) by

$$
\text { MCR }=\frac{R}{\int_{0}^{\infty} x d t}
$$

The curve of the hormone disappearance from the blood can be described as the sum of three exponentials. The first one, constructed with the very first plots (within the first minute $=$ two to three first samples), was attributed to the tracer dilution in the 
plasma; thus $x(t)$ was described by a double exponential: $x(t)=A e^{-\alpha t}+B e^{-\beta t}$ and then

$$
\mathrm{MCR}=\frac{\alpha \beta}{\beta A+\alpha B}
$$

$\alpha, \beta, A$, and $B$ were calculated by linear regression analysis of the plasma disappearance curve after logarithmic transformation. Constant infusion: At the steady state, when the plasma radioactive concentration $(x)$ has become stable, with the infusion at a constant rate $(r)$, counterbalancing exactly metabolism of the labeled steroid, then MCR $=r / x \mathrm{ml}$ of plasma per time unit. MCR was calculated for each fish from the mean of all the radioactive concentrations during the steady state. Then it was expressed in Table 2 as a mean \pm SE. In both cases, MCR was calculated per kilogram of body weight.

Statistics. MCR values of studied oogenesis stages were compared with Wilcoxon-Mann and Whitney nonparametric tests (Snedecor and Cochran, 1971).

\section{RESULTS}

\section{Steady-State Characteristics in Animals under Constant Infusion}

A steady state was reached within 1 to 4 $\mathrm{hr}$ in the constant infusion method. Then plasma concentrations of radioactivity remained stable (Figs. 1 and 2) until the end of infusion ( 22 to $50 \mathrm{hr}$ ).

\section{Identification of the Plasma Radioactivity}

In blood samples collected after the single $E_{2}-17 \beta$ injection, $95 \%$ of tritiated

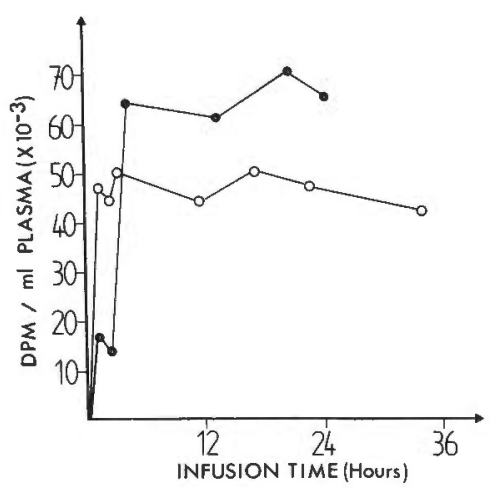

FIG. 1. $\mathrm{E}_{2}-17 \beta$ plasma radioactivity during constant infusion of rainbow trout at two different oogenesis stages: advanced endogenous $(O)$ and advanced exogenous (-) vitellogenesis.

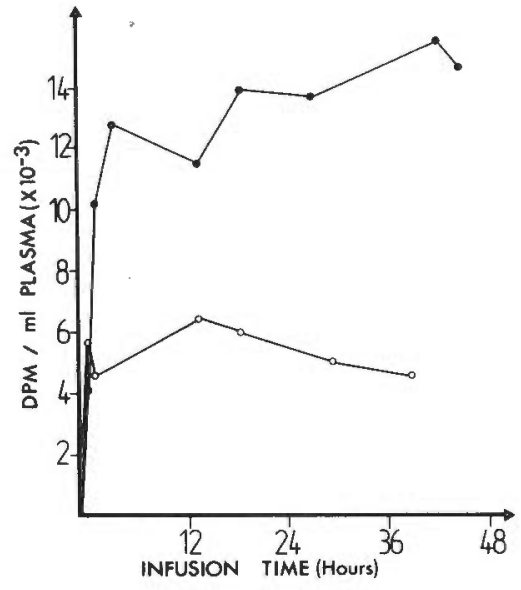

FIG. 2. $E_{2}-17 \beta$ plasma radioactivity during constant infusion of rainbow trout at two different oogenesis stages: oocyte maturation $(O)$ and ovulation $(0)$.

counts, recovered with solvent extraction, could be attributed to estradiol, after chromatography on Sephadex LH-20 columns. Thus, the disappearance curves of the total extractable radioactivity from the plasma and those of radioactive estradiol were parallel and almost superimposed (Fig. 3).

In samples obtained in the constant infusion method, $90 \%$ of the total plasma radioactivity was represented by unconjugated

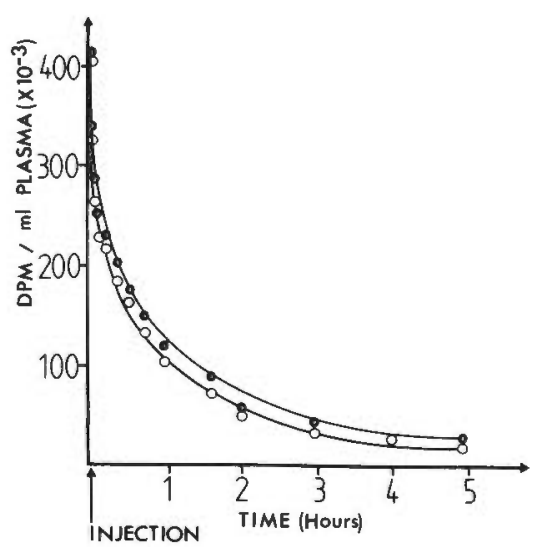

Fig. 3. Plasma disappearance curves of total extractable radioactivity $(0$, cyclohexane:ethylacetate, 50:50) and radioactive estradiol $(O$, purified by Sephadex LH-20 chromatography) after injection of one dose of $\left[2,4,6,7-{ }^{3} \mathrm{H}\right]$ estradiol in cardiovascular system. 
steroids (extractable radioactivity). These latter samples, after chromatography on HPLC using the ${ }^{14} \mathrm{C}$ activity to assess the recovery, were composed of $90 \% \mathrm{E}_{2}-17 \beta$.

The identification of estradiol was confirmed for two constant infusion experiments after column chromatography (normal pressure chromatography on Sephadex LH-20 and HPLC on C-18 Bondapack) by the constancy of the ${ }^{14} \mathrm{C} /{ }^{3} \mathrm{H}$ ratio through successive crystallizations (Table 1).

For three animals treated with constant infusion, estrone fractions, obtained after chromatography on Sephadex LH-20 column, were measured as representing 7 to $25 \%$ of estradiol (Fig. 4).

\section{Plasma Disappearance of Radioactive Estradiol after Single Injection}

The patterns of the $E_{2}-17 \beta$ disappearance curves in the three different oocyte developmental stages were similar (Fig. 5). These curves could be described by the sum of two exponentials.

\section{Metabolic Clearance Rate}

Single injection. MCR values (Table 2) decreased from the beginning of exogenous vitellogenesis $(23.1$ to $34.8 \mathrm{ml} / \mathrm{hr} / \mathrm{kg})$ up to advanced exogenous vitellogenesis stages ( 18.5 to $23.8 \mathrm{ml} / \mathrm{hr} / \mathrm{kg}$ ). Highest values were found during the first stages of oocyte maturation ( 32.8 to $45.2 \mathrm{ml} / \mathrm{hr} / \mathrm{kg})$.

Constant infusion. MCR remained constant from the postovulation period up to the beginning of exogenous vitellogenesis (21 to $35.5 \mathrm{ml} / \mathrm{hr} / \mathrm{kg}$; mean $=27.9 \mathrm{ml} / \mathrm{hr} /$ $\mathrm{kg})$; it fell to the lowest value $(14 \mathrm{ml} / \mathrm{hr} / \mathrm{kg})$ during advanced exogenous vitellogenesis. Then a clear rise occurred during oocyte maturation ( 40.7 to $45 \mathrm{ml} / \mathrm{hr} / \mathrm{kg}$ ).

\section{Statistical Test}

Data from both methods were comparable, and thus they were gathered to test statistically (Wilcoxon-Mann and Whitney nonparametric tests) the differences between the various stages. The MCR values measured at oocyte maturation were tested against those measured at the postovulation period up to advanced exogenous vitellogenesis or up to the beginning of exogenous vitellogenesis. The values at the oocyte maturation stage were always highly significantly greater than the others. Furthermore, the values of advanced exogenous vitellogenesis were significantly lower than those of the stages extending from the postovulation period up to the beginning of exogenous vitellogenesis.

\section{DISCUSSION}

The determination of the MCR of estradiol is necessary to understand the regulation of its plasma levels during ovogenesis. For such a study to be valid requires that the injected labeled hormone should not disturb the normal distribution and metabolism of the endogenous steroid (Tait, 1963). In the present work, single injection produced an initial plasma concentration of 0.5 to $1.5 \mathrm{ng}$ of the labeled steroid per milliliter of blood. This value is below or equal to the endogenous hormone level. In the constant infusion method, the highest rate was $2.9 \mathrm{ng} / \mathrm{hr}$ for a fish weighing $2.1 \mathrm{~kg}$. The blood volume of such a fish is estimated to

TABLE 1

Changes in the ${ }^{14} \mathrm{C} /{ }^{3} \mathrm{H}$ Ratio through Successive Purification Stages of the E $2_{2}-17 \beta$ Fraction

\begin{tabular}{cccccc}
\hline $\begin{array}{c}\text { Number } \\
\text { of the } \\
\text { females }\end{array}$ & $\begin{array}{c}\text { Sephadex } \\
\text { LH-20 }\end{array}$ & HPLC & $\begin{array}{c}\text { First } \\
\text { crystallization }\end{array}$ & $\begin{array}{c}\text { Second } \\
\text { crystallization }\end{array}$ & $\begin{array}{c}\text { Third } \\
\text { crystallization }\end{array}$ \\
\hline 6 & 0.27 & 0.23 & 0.22 & 0.23 & -32 \\
2 & 0.35 & 0.34 & 0.32 & 0.33 & 0.32 \\
\hline
\end{tabular}




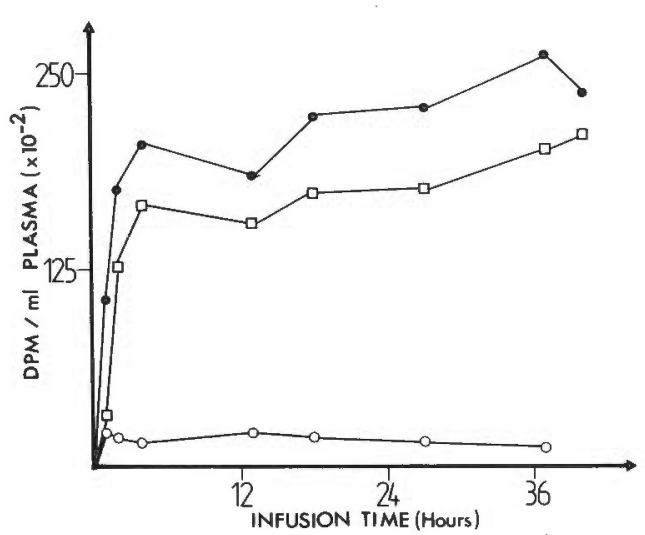

FIG. 4. Plasma radioactivity in a rainbow trout during constant infusion: total plasma radioactivity (O), plasma radioactivity attributed to $E_{2}-17 \beta$ after HPLC ( $\square$ ), and that attributed to $E_{1}$ after Sephadex LH-20 (O).

be $70 \mathrm{ml}$, according to a ratio of 3.5 to $4.5 \%$ of blood to body weight (Smith, 1966; Nikinmaa et al., 1981). Thus without any epuration, the dilution of the labeled hormone in the whole blood volume would produce an increase of $42 \mathrm{pg} / \mathrm{ml}$ in $\mathrm{E}_{2}-17 \beta$ concentration, compared with a level of $200 \mathrm{pg} / \mathrm{ml}$ measured by RIA before the be-

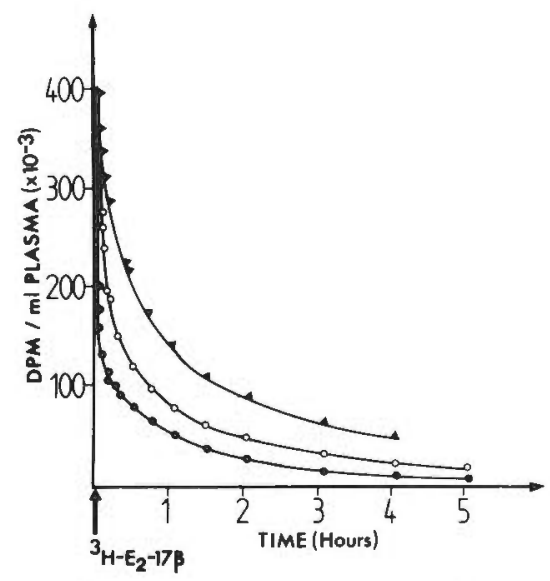

FIG. 5. Plasma disappearance curves of radioactive estradiol after a single injection of $\left[2,4,6,7-{ }^{3} \mathrm{H}\right] \mathrm{estra}$ diol in three female rainbow trout at various sexual stages: Beginning $(\boldsymbol{A})$ and advanced $(\mathrm{O})$ exogenous vitellogenesis or oocytes with migrating germinal vesicle (O). ginning of the perfusion. In both cases, this variation is relatively low. Therefore, our experimental conditions permit the measurement of MCR.

In both single injection and constant infusion methods, the same MCR changes and very similar values were obtained; in both cases, plasma radioactivity plotted against time gave reproducible curve shapes. Thus, the two techniques seem to be adequate for MCR measurements, and the sum of two exponentials can reasonably be used to fit the plasma $E_{2}-17 \beta$ disappearance curve after single injection.

Most of the nonconjugated radioactivity can be attributed to $E_{2}-17 \beta$ both in single injection and constant infusion samples, as also was reported in the immature eel by Querat et al. (1985) after Celite chromatography. However, $\mathrm{E}_{2}-17 \beta$ has been identified by following the constancy of the ${ }^{3} \mathrm{H} /{ }^{14} \mathrm{C}$ ratio during successive crystallizations in only a few of our samples. Plasma radioactivity decreased rapidly; thus, the amount of labeled steroid in each sampling became too small for these purification stages. Nevertheless, Sephadex LH-20 chromatography appears sufficient for attaining a high degree of purity (Table 1).

Mammal and hen $\mathrm{E}_{2}-17 \beta$ MCR data are 30 to 100 times (Reed and Murray, 1979) and 125 to 200 times (Tsang and Grunder, 1984) higher, respectively, than ours. By contrast, the MCR of immature eel (Querat et al., 1985) is about 40 times lower than that of our values for the trout. These discrepancies in MCR among different fish species, mammals, and birds might be explained, at least in part, by specific thermoregulation modes or specific sex steroid-binding protein (SBP) systems. Thermoregulation modes may play a significant role in these specific rates as temperature in fish is known to influence hepatic and ovarian metabolic activities (Kime and Saksena, 1980; Manning and Kime, 1984). Specific SBP systems suggest another possible explanation. Sandberg et al. (1966) 
TABLE 2

Metabolic Clearance Rate $(\mathrm{ml} / \mathrm{hr} / \mathrm{kg})$ of $\mathrm{E}_{2}-17 \beta$ in RaInbow Trout at Various Stages of OOGENESis ESTIMATED by Both SINGLE INJECTION AND CONSTANT INFUSION METHOdS

\begin{tabular}{|c|c|c|c|c|c|c|c|c|c|c|c|c|c|}
\hline \multirow{3}{*}{$\begin{array}{c}\text { Method } \\
\begin{array}{c}\text { Constant } \\
\text { infusion }\end{array}\end{array}$} & \multirow{2}{*}{\multicolumn{3}{|c|}{$\begin{array}{c}\text { Advanced } \\
\text { endogenous } \\
\text { vitellogenesis }\end{array}$}} & \multirow{2}{*}{\multicolumn{2}{|c|}{$\begin{array}{l}\text { Beginning } \\
\text { of } \\
\text { exogenous } \\
\text { vitellogenesis }\end{array}$}} & \multirow{2}{*}{\multicolumn{2}{|c|}{$\begin{array}{c}\text { Advanced } \\
\text { exogenous } \\
\text { vitellogenesis }\end{array}$}} & \multicolumn{3}{|c|}{$\begin{array}{c}\text { Oocyte } \\
\text { maturation }\end{array}$} & \multirow{2}{*}{\multicolumn{3}{|c|}{$\begin{array}{c}\text { Post- } \\
\text { ovulation } \\
\text { period }\end{array}$}} \\
\hline & & & & & & & & \multirow{2}{*}{\multicolumn{2}{|c|}{$\begin{aligned} \text { SPGV } \\
45 \\
\pm 1.7\end{aligned}$}} & \multirow{2}{*}{$\begin{array}{r}\text { GVBD } \\
40.7 \\
\pm 0.5\end{array}$} & & & \\
\hline & $\begin{array}{r}25.2 \\
\pm 0.5\end{array}$ & $\begin{array}{r}31.5 \\
\pm 0.6\end{array}$ & $\begin{array}{r}27.2 \\
\pm 0.9\end{array}$ & $\begin{array}{c}31 \\
\pm 1.5\end{array}$ & & $\begin{array}{c}14 \\
\pm 0.4\end{array}$ & & & & & $\begin{array}{r}35.5 \\
\pm 0.3\end{array}$ & $\begin{array}{c}21 \\
\pm 0.9\end{array}$ & $\begin{array}{r}24.1 \\
\pm 0.7\end{array}$ \\
\hline $\begin{array}{l}\text { Single } \\
\text { injection }\end{array}$ & & & & 34.8 & 23.1 & 18.5 & 23.8 & 45.2 & 32.8 & & & & \\
\hline $\begin{array}{l}\text { Mean/ } \\
\text { oocyte } \\
\text { stage }\end{array}$ & & 27.9 & & & & & & & 40.9 & & & 26.8 & \\
\hline
\end{tabular}

Note. SPGV: subperipheral germinal vesicle; GVBD: germinal vesicle breakdown.

have shown that in mammals, the greater a steroid is bound, the less it will be metabolized; and recently, Petra et al. (1985) reported a decrease in the clearance rate of testosterone after the infusion of pure SBP. In fish steroid-binding capacities are higher than those for the mammalian binding system (Wingfield, 1980); it is the case for teleosts in which a sex steroid-binding protein has been described (trout: Fostier and Breton, 1975; eel: Querat et al., 1983). Thus, we can assume that differences in SBP characteristics among species would result in different $M C R$ values. In the present study, MCR values were shown to change during oogenesis: these values were stable from the postovulation period throughout endogenous vitellogenesis and early exogenous vitellogenesis. They then decreased significantly during advanced exogenous vitellogenesis and increased clearly at the onset of oocyte maturation. Three stages of ovarian development were examined by both single injection and constant infusion methods; for each of them, MCR measurements were comparable (Table 2). Our data, derived from two methods, indicate that the previously described slow rise in circulating $E_{2}-17 \beta$ levels occurring at early vitellogenesis (Lambert et al., 1978; Whitehead et al., 1978; Scott et al., 1980; Van Bohemen and Lambert, 1981; Breton et al., 1983) is accompanied by a quite stable basal MCR (endogenous vitellogenesis $27.9 \mathrm{ml} / \mathrm{hr} / \mathrm{kg}$ and beginning of exogenous vitellogenesis $28.8 \mathrm{ml} / \mathrm{hr} / \mathrm{kg}$ ). Since the MCR remained constant, in this early vitellogenic stage, the slight estrogen increase may have been the consequence of an augmentation of its secretion rate by the ovaries. Later, at the exogenous vitellogenesis and preovulation stages, when some of the most important events for the oocyte begin (vitellogenin synthesis and incorporation, hormonal environment changes), there is a direct relation between MCR and circulating $\mathrm{E}_{2}-17 \beta$ levels. Variations in plasma $\mathrm{E}_{2}-17 \beta$ levels are parallel to its MCR: the lowest MCR (range $=14-23.8 \mathrm{ml} / \mathrm{hr} / \mathrm{kg}$, mean $=18.7$ $\mathrm{ml} / \mathrm{hr} / \mathrm{kg}$ ) occurred during advanced exogenous vitellogenesis, an oogenetic stage known for the highest plasma $E_{2}-17 \beta$ concentrations. So when the MCR decreased, $E_{2}-17 \beta$ circulating levels increased. In the same way, the highest MCR (range = $32.8-45.2 \mathrm{ml} / \mathrm{hr} / \mathrm{kg}$, mean $=40.9 \mathrm{ml} / \mathrm{hr} / \mathrm{kg}$ ) coincided with a decrease in estradiol during gametogenesis. A clear increase of the clearance activity is thus shown when the vitellogenic hormone is decreasing. Seasonal variations in the binding protein capacity might exist in the female rainbow trout, which would explain, at least partially, the variations in MCR. Differences in steroid MCR (testosterone) between males and females have been reported in skate (Fletcher et al., 1969) but, to our knowl- 
edge, no MCR variations have been shown in relation to the development of gametogenesis in fish. $\mathrm{Ng}$ and Idler (1980) found that in flounder and in salmonids, hypophysectomy was followed by the disappearance of circulating SBP, which could be restored by treatment of both glycoproteic and nonglycoproteic gonadotropins. $\mathrm{GtH}$ is one component of the circulating hormonal environment submitted to important variations during the latest stages of oocyte development in rainbow trout; thus, it could underlie a possible regulation of these SBP capacities. In addition, hypophyseal hormones appear to play a role in the regulation of the metabolism of androstenedione by liver microsomes from juvenile rainbow trout (Hansson and Gustafsson, 1981). Such a regulation may exist for the hepatic metabolism of estradiol-17 $\beta$ (Hansson and Rafter, 1983). Following the end of vitellogenesis, the decrease in $E_{2}-17 \beta$ is probably essential for the establishment of a hormone environment required for oocyte maturation (Jalabert and Fostier, 1984b).

Sexual steroids have been studied mainly with regard to their secretion or their circulating levels but more attention should be paid to their clearance, especially during periods of sudden or dramatic variations in their concentration.

\section{ACKNOWLEDGMENTS}

The helpful discussions with Drs. J. Leloup-Hatey and B. Querat are gratefully acknowledged. The authors thank Mrs. A. Moloney and J. Hall for their help in translating the manuscript. The investigations were supported by Institut National de la Recherche Agronomique and Centre National de la Recherche Scientifique (ATP 9-82-115).

\section{REFERENCES}

Axelrod, L. R., Matthijssen, C., Goldzieher, J. W., and Pullian, J. E. (1965). Definitive identification of microquantities of radioactive steroids by recrystallization to constant specific activity. Acta Endocrinol. 49 (Suppl. 99), 1-77.

Bommelaer, M. C., Billard, R., and Breton, B. (1981). Changes in plasma gonadotropin after ovariectomy and estradiol supplementation at different stages at the end of the reproductive cycle in the rainbow trout (Salmo gairdneri R.). Reprod. Nutr. Dev. 21, 989-997.

Breton, B., Fostier, A., Zohar, Y., Lebail, P. Y., and Billard, R. (1983). Gonadotropine glycoproteique maturante et oestradiol-17 $\beta$ pendant le cycle reproductcur chez la truite fario (Salmo trutta) $\mathrm{fe}$ melle. Gen. Comp. Endocrinol. 49, 220-231.

Bry, C., and Zohar, Y. (1980). Dorsal aorta catheterization in rainbow trout (Salmo gairdneri). II. Glucocorticoid levels, hematological data and resumption of feeding for five days after surgery. Reprod. Nutr. Dev. 20, 1825-1834.

Donaldson, E. M., and Fagerlund, U. H. M. (1968). Changes in the cortisol dynamics of sockeye salmon (Oncorhynchus nerka) resulting from sexual maturation. Gen. Comp. Endocrinol. 11, $552-561$.

Donaldson, E. M., and Fagerlund, U. H. M. (1969). Cortisol secretion rate in gonadectomized female sockeye salmon (Oncorhynchus nerka). Effects of estrogen and cortisol treatment. J. Fish. Res. Board Canad. 26, 1789-1799.

Fagerlund, U. H. M., and Donaldson, E. M. (1969). The effect of androgens on the distribution and secretion of cortisol in gonadectomized male sockeye salmon (Oncorhynchus nerka). Gen. Comp. Endocrinol. 12, 438-448.

Fagerlund, U. H. M., and Donaldson, E. M. (1970). Dynamics of cortisone secretion in sockeye salmon (Oncorhynchus nerka) during sexual maturation and after gonadectomy. J. Fish. Res. Board Canad. 27, 2323-2331.

Fagerlund, U. H. M., and Dye, H. (1979). Depletion of radioactivity from yearling coho salmon (Oncorhynchus kisutch) after extended ingestion of anabolically effective doses of $17 \alpha$-methyltestosterone-1, $2{ }^{3} \mathrm{H}$. Aquaculture 18, $303-315$.

Fagerlund, U. H. M., and McBride, J. R. (1978). Distribution and disappearance of radioactivity in blood and tissues of Coho salmon (Oncorhynchus kisutch), after oral administration of ${ }^{3} \mathrm{H}$-testosterone. J. Fish. Res. Board Canad. 35, 893-900.

Fletcher, G. L., Hardy, D. C., and Idler, D. R. (1969). Testosterone production and metabolic clearance rates in sexually mature male and female skate (Raja radiata). Endocrinology 85, 552-560.

Fostier, A., and Breton, B. (1975). Binding of steroids by plasma of a teleost, the rainbow trout Salmo gairdneri. J. Steroid Biochem. 6, 345-351.

Fostier, A., and Jalabert, B. (1982). Physiological basis of practical means to induce ovulation. In "Proceed. Intern. Symp. Reprod. Physiol. Fish" (C. J. J. Richter and H. J. Th. Goos, Eds.), pp. 164-173. PUDOC, Wageningen.

Fostier, A., Jalabert, B., and Terqui, M. (1973). Action prédominante d'un dérivé hydroxylé de la progestérone sur la maturation in vitro des ovo- 
cytes de la truite arc-en-ciel, Salmo gairdneri. C.R. Acad. Sci. Paris 277, 421-423.

Fostier, A., Weil, C., Terqui, M., Breton, B., and Jalabert, B. (1978). Plasma estradiol-17 $\beta$ and gonadotropin during ovulation in rainbow trout (Salmo gairdneri R.). Ann. Biol. Anim. Biochem. Biophys. 18, 929-936.

Gabe, M. (1968) "Techniques Histologiques." Masson, Paris.

Goodman, J. H., and Butler, D. G. (1976). Cortisol dynamics in North American eels (Anguilla rostrata Le Sueur). Gen. Comp. Endocrinol. 28, 292-298.

Hansson, T., and Gustafsson, J. A. (1981). In vitro metabolism of 4-androstene-3,17-dione by hepatic microsomes from the rainbow trout (Salmo gairdnerii); Effect of hypophysectomy and oestradiol17ß. J. Endocrinol. 90, 103-112.

Hansson, T., and Rafter, J. (1983), In vitro metabolism of oestradiol- $17 \beta$ by liver microsomes from juvenile rainbow trout, Salmo gairdneri. Gen. Comp. Endocrinol. 49, 490-495.

Henderson, I. W., Sadi, M. N., and Hargreaves, G. (1974). Studies on the production and metabolic clearance rates of cortisol in the European eel, Anguilla anguilla (L.). J. Steroid Biochem. 5, $701-707$.

Idler, D. R., Truscott, B., Freeman, H. C., Chang, V., Schmidt, P. J., and Ronald, A. P. (1963). In vivo metabolism of steroid hormones by sockeye salmon. (A) Impaired hormone clearance in mature and spawned pacific salmon (Oncorhynchus nerka). (B) Precursors of 11-ketotestosterone. Canad. J. Biochem. Physiol. 41, 875-879.

Idler, D. R., and Truscott, B. (1969). Production of $1 \alpha$-hydroxycorticosterone in vivo and in vitro by Elasmobranchs. Gen. Comp. Endocrinol. Suppl. 2, 325-330.

Jalabert, B. (1975). Modulation par différents stéroides non maturants de l'efficacité de la $17 \alpha$-hydroxy-20ß-dihydroprogesterone ou d'un extrait gonadotrope sur la maturation intrafolliculaire in vitro des ovocytes de la truite arc en ciel, Salmo gairdnerii. C.R. Hebd. Séances Acad. Sci. 281, 811-814.

Jalabert, B. (1976). In vitro oocyte maturation and ovulation in rainbow trout (Salmo gairdneri), Northern Pike (Esox lucius) and Goldfish (Carassius auratus). J. Fish. Res. Board Canad. 33(4), 974-988.

Jalabert, B., and Fostier, A. (1984a). The modulatory effect in vitro of oestradiol-17 $\beta$, testosterone or cortisol on the output of $17 \alpha$-hydroxy-20 $\beta$-dihydroprogesterone by rainbow trout (Salmo gairdneri) ovarian follicles stimulated by the maturational gonadotropins s-GtH. Reprod. Nutr. Dev. 24, 127-136.

Jalabert, B., and Fostier, A. (1984b). The follicular sensitivity in vitro to maturation inducing hormones in rainbow trout, Salmo gairdneri: Role of oestradiol-17 $\beta$. Aquaculture 43, 1-11.

Jalabert, B., Goetz, F. W., Breton, B., Fostier, A., and Donaldson, E. (1978). Precocious induction of oocyte maturation and ovulation in Coho salmon, Oncorhynchus kisutch. J. Fish. Res. Board Canad. 35, 1423-1429.

Johnstone, R., Macintosh, D. J., and Wright, R. S. (1983). Elimination of orally administered $17 \alpha-$ methyltestosterone by Oreochromis mossambicus (Tilapia) and Salmo gairdneri (Rainbow trout) juveniles. Aquaculture 35, 249-257.

Johnstone, R., Simpson, T. H., and Youngson, A. F. (1978). Sex reversal in salmonid culture. Aquaculture 13, 115-134.

Kagawa, H., Young, G., and Nagahama, Y. (1983). Relationship between seasonal plasma estradiol$17 \beta$ and testosterone levels and in vitro production by ovarian follicles of amago salmon (Oncorhynchus rhodurus). Biol. Reprod. 29, 301-309.

Kime, D. E., and Saksena, D. N. (1980). The effect of temperature on the hepatic catabolism of testosterone in the rainbow trout (Salmo gairdneri) and the goldfish (Carassius auratus). Gen. Comp. Endocrinol. 42, 228-234.

Lambert, J. G. D., Bosman, G. I. C. G. M., Van den Hurk, R., and Van Oordt, P. G. W. J. (1978). Annual cycle of plasma oestradiol-17 $\beta$ in the female trout (Salmo gairdneri). Ann. Biol. Anim. Biochem. Biophys. 18, 923-927.

Leloup-Hatey, J. (1974). Influence de l'adaptation à l'eau de mer sur la fonction interrenalienne de l'anguille. Gen. Comp. Endocrinol. 24, 28-37.

Leloup-Hatey, J. (1976). Méthode de mesure des vitesses d'épuration métabolique et de secrétion du cortisol chez l'anguille (Anguilla anguilla L.). Canad. J. Physiol. Pharmacol. 54, 262-276.

Lone, K. P., and Matty, A. J. (1981). Uptake and disappearance of radioactivity in blood and tissues of carp (Cyprinus carpio) after feeding ${ }^{3} \mathrm{H}$-testosterone. Aquaculture 24, 315-326.

Manning, N. J., and Kime, D. E. (1984). Temperature regulation of ovarian steroid production in the common carp, Cyprinus carpio L., in vivo and in vitro. Gen. Comp. Endocrinol. 56, 376-388.

Myers, S. F., and Avila, V. L. (1980). Tritiated 17 $\beta$-estradiol uptake by the brain and other tissues of the cichlid jewel fish, Hemichromis bimaculatus. Gen. Comp. Endocrinol. 42, 203-211.

$\mathrm{Ng}, \mathrm{T}$. B., and Idler, D. R. (1980). Gonadotropic regulation of androgen production in flounder and Salmonids. Gen. Comp. Endocrinol. 42, 25-38.

$\mathrm{Ng}$, T. B., and Idler, D. R. (1983). Yolk formation and differentiation in teleost fishes. In "Fish Physiology" (W. S. Hoar, D. J. Randall, and E. M. Donaldson, Eds.), Vol. 9, Part A, pp. 373-404. Academic Press, New York. 
Nikinmaa, M., Soivio, A., and Railo, E. (1981). Blood volume of Salmo gairdneri: Influence of ambient temperature. Comp. Biochem. Physiol. 69, 767-769.

Owen, W. H., and Idler, D. R. (1972). Identification and metabolic clearance of cortisol and cortisone in a marine teleost, the sea raven Hemipterus americanus gmelin (Family Scorpaenidae). J. Endocrinol. 3, 101-112.

Pankhurst, N. W., and Stacey, N. E. (1985). The effect of $17 \beta$-estradiol on spontaneous ovulation in goldfish, Carassius auratus. Canad. J. Zool. 63, 2979-2981.

Patino, R., Schreck, C. B., and Redding, J. M. (1985). Clearance of plasma corticosteroids during smoltification of coho salmon, Oncorhynchus kisutch. Comp. Biochem. Physiol. A 82(3), 531-535.

Petra, P. H., Stanczyk, F. Z., Namkung, P. C., Fritz, M. A., and Novy, M. J. (1985). Direct effect of sex steroid binding protein (SBP) of plasma on the metabolic clearance rate of testosterone in the rhesus Macaque. J. Steroid Biochem. 22(6), 739-746.

Querat, B., Leloup-Hatey, J., and Hardy, A. (1982). Ovarian steroid metabolism in the immature european eel (Anguilla anguilla). In "Proceed. Intern. Symp. Reprod. Physiol. Fish" (C. J. J. Richter and H. J. Th. Goos, Eds.), p. 112. PUDOC, Wageningen.

Querat, B., Hardy, A., and Leloup-Hatey, J. (1983). Etude de la liaison plasmatique des stéroides sexuels et du cortisol chez l'anguille argentée femelle (Anguilla anguilla L.) C.R. Acad. Sci. Ser. Ser. $3297,119-122$.

Querat, B., Hardy, A., and Leloup-Hatey, J. (1985). Niveaux plasmatiques, vitesses de clairance métabolique, et vitesses de secrétion de la testosterone et de l'oestradiol-17 $\beta$ chez l'anguille ( $A n$ guilla anguilla L.) argentée. Gen. Comp. Endocrinol. 59, 482-493.

Reed, M. J., and Murray, M. A. F. (1979). The oestrogens. In "Hormones in Blood" (C. H. Gray and V. H. T. James, Eds.), Vol. 3, pp. 263-353. Academic Press, New York.

Sandberg, A. A., Rosenthal, H., Schneider, S. L., and Slaunwhite, W. R. (1966). Protein steroid interactions and their role in the transport and metabolism of steroids. In "Steroid Dynamics" (G. Pincus, T. Nakao, and J. F. Tait, Eds.), pp. 1-59. Academic Press, New York.

Schreck, C. B. (1973). Uptake of ${ }^{3} \mathrm{H}$ testosterone and influence of an antiandrogen in tissues of rainbow trout (Salmo gairdneri). Gen. Comp. Endocrinol. 21, 60-68.

Scott, A. P., Bye, V. J., and Baynes, S. M. (1980). Seasonal variations in sex steroids of female rainbow trout (Salmo gairdneri Richardson). $J$. Fish Biol. 17, 587-592.

Scott, A. P., Sumpter, J. P., and Hardiman, P. A.
(1983). Hormones changes during ovulation in the rainbow trout (Salmo gairdneri Richardson). Gen. Comp. Endocrinol. 49, 128-134.

Smith, L. S. (1966). Blood volumes of three salmonids. J. Fish Res. Board Canad. 23, 14391446.

Snedecor, G. W., and Cochran, W. G. (1971). "Méthodes Statistiques." A.C.T.A., Paris.

Sower, S. A., and Schreck, C. B. (1982). Steroid and thyroid hormones during sexual maturation of coho salmon (Oncorhynchus kisutch) in seawater or fresh water. Gen. Comp. Endocrinol. 47, 42-53.

Tait, J. F. (1963). Review: The use of isotopic steroids for the measurement of production rates in vivo. J. Clin. Endocrinol. Metab. 23, 1285-1297.

Truscott, B., Kane, K. M., and Idler, D. R. (1977). Distribution and metabolism of $1 \alpha$-hydroxycorticosterone in the skate Raja radiata. Comp Biochem. Physiol. B 56, 341-345.

Tsang, C. P. W., and Grunder, A. A. (1984). Production, Clearance rates and metabolic rate of estradiol-17 $\beta$ in the plasma of the laying hen. Steroids $43,71-84$.

Van Bohemen, C. H. G., and Lambert, J. G. D. (1981). Estrogen synthesis in relation to estrone, estradiol and vitellogenin plasma levels during the reproductive cycle of the female rainbow trout, Salmo gairdneri. Gen. Comp. Endocrinol. 45, $105-114$.

Van der Kraak, G., Dye, H. M., and Donaldson, E. M. (1984). Effects of LH-RH and DesGly ${ }^{10}\left[\mathrm{D}-\mathrm{Ala}^{6}\right] \mathrm{LH}-\mathrm{RH}$-ethylamide on plasma sex steroid profiles in adult female coho salmon ( $\mathrm{On}$ corhynchus kisutch). Gen. Comp. Endocrinol. 55, $36-45$.

Whitehead, C., Bromage, N. R., and Forster, J. R. (1978). Seasonal changes in reproductive function of the rainbow trout (Salmo gairdneri). J. Fish Biol. 12, 601-608.

Wingfield, J. C. (1980). Sex steroid-binding proteins in vertebrate blood. In "Hormones, Adaptation and Evolution" (S. Ishii et al., Eds.), pp. 135-144. Japan Sci. Soc. Press, Tokyo.

Young, G., Kagawa, H., and Nagahama, Y. (1983). Evidence for a decrease in aromatase activity in the ovarian granulosa cells of amago salmon ( $\mathrm{On}$ corhynchus rhodurus) associated with final oocyte maturation. Biol. Reprod. 29, 310-315.

Zohar, Y. (1980). Dorsal aorta catheterization in rainbow trout (Salmo gairdneri). I. Its validity in the study of blood gonadotropin patterns. Reprod. Nutr. Dev. 20, 1811-1823.

Zohar, Y. (1982). L'évolution de la pulsatilité et des cycles nycthéméraux de la sécrétion gonadotrope chez la truite arc en ciel femelle, en relation avec le cycle sexuel annuel et par rapport à l'activité stéroidogène de l'ovaire. Thèse de Doctorat d'Etat ès Sciences Naturelles. Université Paris VI. 